特集「第11回大会」

原著論文

ヒューマンデザインテクノロジーに基づいたインタフェース構築手法

ー ホームセキュリティシステムのコントローラ改善事例 一

平田 一郎*,**, 後藤 泰徳*, 山岡 俊樹**

* 兵庫県立工業技術センターものづくり開発部, ** 和歌山大学システム工学部

\title{
Proposal of User-interface Method Based on Human Design Technology
}

\author{
- Case Study of Improvement of a Home Security System's Controller - \\ Ichiro HIRATA*, **, Yasunori GOTO* and Toshiki YAMAOKA** \\ * Product Innovation Dept, Hyogo prefectural institute of technology, 3-1-12 Yukihira-cho, Suma-ku, kobe-shi, Hyogo 654-0037, Japan \\ ** Faculty of Systems Engineering, Wakayama University, 930 Sakaedani, Wakayama-shi, Wakayama 640-8510, Japan
}

\begin{abstract}
The purpose of this study is to develop a user interface design method based on Human Design Technology (HDT). HDT has useful procedure to develop product design, however doesn't have clear procedure in case of user interface. So, we propose a method that is based on HDT to develop the user interface. This method has three steps to design the user interface. These steps are as follows. (1) description of interface specifications, (2) visualization of interface sequence and hierarchy of user tasks, and (3) prototyping of the user interface. A home security system's controller which was redesigned by the method was evaluated for verifying the effectiveness of this method. The improved user interface design was compared with the current controller by usability evaluation. The results of evaluation show this method is also useful and effective to develop the user interface.
\end{abstract}

Keywords : Human Design Technology, Structured Concept, User Interface

\section{1. は じめ に}

人材的な面や時間的な面で余裕のない中小企業の現場で は，企画や製品コンセプトの立案に時間を割くことが難し く，また，そのような経験者も少ない $[1]$ ，そこで，製品開 発の経験が少ない設計者でも論理的に製品開発が行える手 法として, ヒューマンデザインテクノロジー(以下 HDT) [2] が提唱されており，中小企業での活用事例も報告されている [3, 4]. HDTは, 「構造化コンセプト」と呼ばれる製品コン セプトを作成するのが特徵である。構造化コンセプトとは, コンセプトを構成するキーワード（以下コンセプト項目）を ツリー構造により図解し，各コンセプト項目にウェイト付け を行う方法である.コンセプト項目にウェイト付けを行うこ とで，製品仕様の優先項目が明確となり，開発工程の後戻り が少なくなるため, 開発期間の短縮化が可能となる。また, 製品開発プロセスの一部を数值化し明確化することで, 経験 の浅い設計者でも開発可能な手法となっている.このHDT のデザイン項目は，種々の製品開発でも活用できるよう工夫 されている。 その反面，インタフェース特有の設計条件であ る画面の流れ (以降シーケンス) や階層構造の可視化方法に ついては言及されていない。 これまで，HDTを活用したイ ンタフェースの開発事例が報告されていない要因として，イ ンタフェース特有の設計方法が不明瞭であることが考えら れる。しかし，製品の使いやすさを大きく左右するインタ
フェースについて, 企業からの開発要望も多く [5], 中小 企業の現場で活用可能なインタフェースの開発手法が望ま れている.

そこで本研究は, 中小企業の現場で活用されている製品開 発手法（HDT）をもとに，インタフェース開発に特化した 開発手法を提案する。具体的には，構造化コンセプトにより 決定したインタフェースの設計方針に基づき，シーケンスお よびタスクフローの可視化を行い，操作タスクをシミュレー ションするためのプロトタイプによりインタフェースを評 価・検証する方法である.

本稿では, 中小企業が開発したホームセキュリティシステ ムを実例として，上記手法によりインタフェース改善を試み た。さらに, 改善インタフェース案と現行インタフェースに ついて，プロトコル分析のタスク達成率による定量評価と, 主観評価による定性評価により操作の比較を行い，提案手法 の有効性について検証した.

\section{2. インタフェース構築プロセス}

本稿で提案するインタフェース構築手法の開発プロセスに ついて述べる。図1に，HDTプロセスにおける本研究の位 置づけを示す．HDTをインタフェース開発に活用に必要な 設計項目として，次の3点をHDTに導入する。

(1) 構造化コンセプトに基づいたインタフェース仕様表の作成

(2)「シーケンス」と「階層構造」の可視化 
(3)インタフェースのシミュレーション可能なプロトタイプ の作成

HDTの「構造化コンセプト作成」プロセスで，コンセプ トに基づいた「インタフェース仕様表」を作成し，システム と想定ユーザを明確化する。「デザイン案の作成」プロセス で,「操作タスクの決定」と「画面デザイン案の作成」を行い, 画面デザイン案をシミュレーション可能なプロトタイプを作 成する，以降，本手法の各プロセスについて説明する。

\section{1 ユーザ要求事項の抽出及び製品の状況把握}

構造化コンセプトを構築するため, ユーザが対象機器に 求めている機能や操作方法に関するユーザ要求事項 [6] を 3Pタスク分析 $[7,8]$ により抽出する (図 2). 各シチュエー ション（図2ではシーン）での行動を細かく分解し（図2で は夕スク),「情報入手」「理解・判断」「操作」の人間の情 報処理プロセスの 3 ポイントから問題点の分析を行う。抽 出した問題点に対する解決案をユーザ要求事項として活用 する。

また，ユーザのアンケートデータをコレスポンデンス分析 [9）や数量化理論而類 [10］などの統計手法を用いて分析す ることで, 既存製品や他社製品に対する価值観や好みなど状 況が把握できる [11].これらの結果も3Pタスク分析と同様, ユーザ要求事項を抽出する方法として有効な手法である.

\section{HDTによるデザインプロセス}

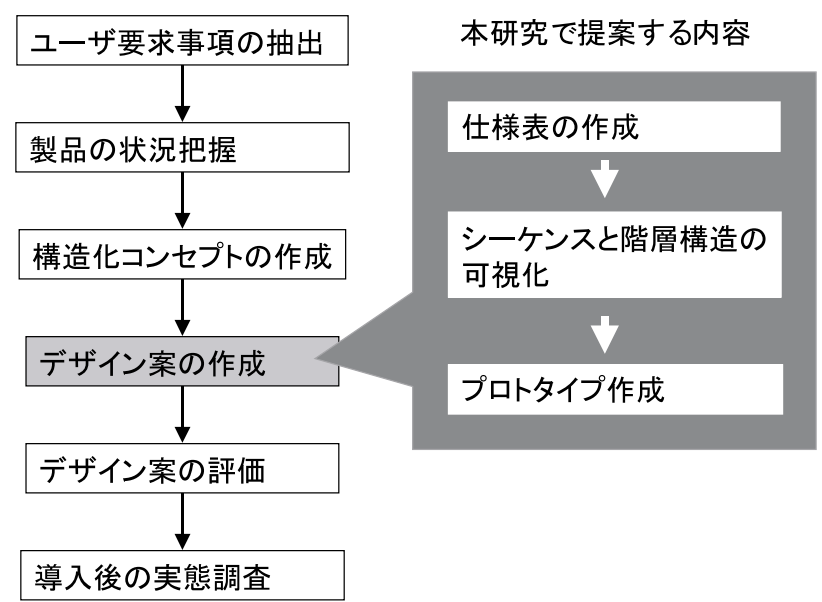

図1 HDT と本研究の関係

\begin{tabular}{|c|c|c|c|c|c|}
\hline \multirow{3}{*}{ 㚈 } & & & & & \\
\hline & \multicolumn{3}{|c|}{ 問题执出 } & \multicolumn{2}{|c|}{ 解決秦 } \\
\hline & 情转入手 & 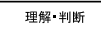 & 操作 & & \\
\hline 電源术夕夕を探す & 手かかいがない & & & 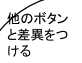 & \\
\hline 電源术夕ンを挪す & & 押した後の反応 & 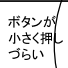 & 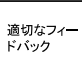 & $\begin{array}{l}\text { 拥しやすい } \\
\text { 大きさ }\end{array}$ \\
\hline 予約术夕ンを探す & $\begin{array}{l}\text { 文字のコントラス } \\
\text { トか优い }\end{array}$ & & & & \\
\hline
\end{tabular}

図2３Pタスク分析による問題抽出
(1)ユーザ要求事項のグループ化

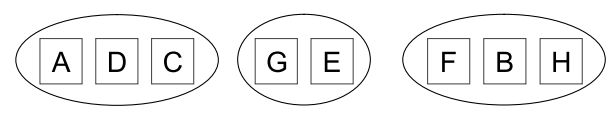

(2)項目のボトムアップ

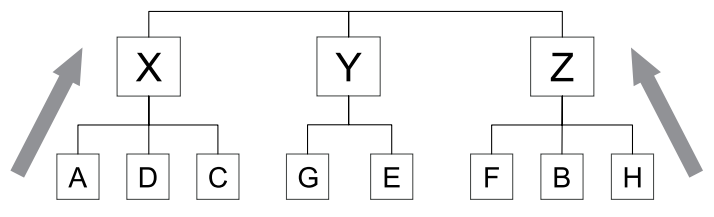

(3)階層化とウェイト付け

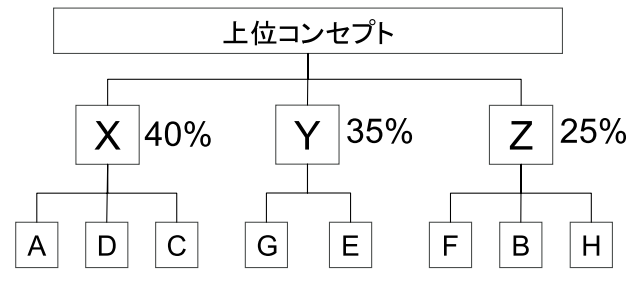

(4)70デザイン項目への対応付け，方針決定

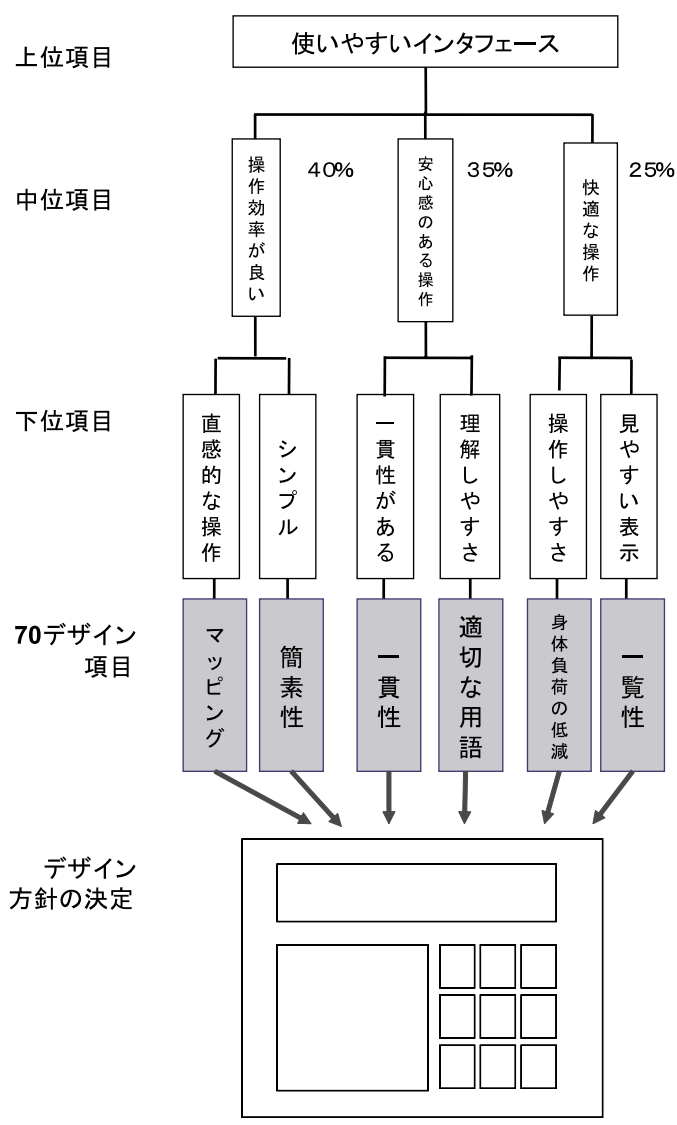

図3 構造化コンセプト作成 


\section{2 構造化コンセプト作成}

抽出したユーザ要求事項に基づき, 構造化コンセプトを作 成する (図3)。抽出したユーザ要求事項（下位項目：図3で は A， B， C . . ) を基にボトムアップ式に階層化を行う。あ るいは, ユーザ要求事項を基にトップダウン式に階層化を 行っても良い. 分類した各グループのコンセプト項目（中位 項目:図3ではX, Y, Z ）によりコンセプトを階層化する（図 3では(2)）中位項目の合計が100パーセントになるように, 各項目のウェイト付けを行う。このウェイト付けは, コンセ プトの方向性を示す大事な作業である。ユーザの声を反映さ せたウエイト付け以外に, 企画者としての意思を反映させた ウェイト付けも可能である.

さらに，下位項目を70デザイン項目に対応させ，インタ フェース全体の設計方針を決定する（図3では(4)）。70デザ イン項目とは,「ベテランのデザイナーやエンジニアが保有 するモノづくりに関する知識を一般化し，モノづくりや可視 化の手がかりとなる項目」である [12]．70デザイン項目を 参照することで, 経験の浅い設計者やデザイナーもコンセプ 卜項目の可視化が比較的容易となる。構造化コンセプトによ り，インタフェース全体の設計方針が明確となる。

\section{3 インタフェース仕様表の作成}

構造化コンセプト作成と並行し, インタフェースの仕様表 を作成する（図4）。仕様表を作成することで，設計項目が より明確となる。「システム側」と「ユーザ側」の両方から 仕様内容を決定する.

システム側では, インタフェースを構成するシステム全般 の仕様について記載する。具体的には, システムの特性, イ ンタフェース機能, タスクの観点から仕様を決定する.

想定ユーザの項目は, ユーザ属性以外に, インタフェース の習熟度や生活スタイル，インタフェースに対するユーザの メンタルモデルを明確にする。ユーザが機器に対する操作イ メージに関する項目である「メンタルモデル明確化」では, メンタルモデルを2種類のモデル (structural model, functional model） [13] から記述する. functional model と は,“どのように使うか”を理解するためのモデルのことで, 文脈依存型の機能モデルである。そそれに対し, structural model は, “どのように動いているか”を理解するためのモ デルのことで, 文脈非依存型の構造モデルのことである [14]. インタフェースに関するメンタルモデルの観点から 説明すると, functional modelは操作ボタンの意味や手順, 内容を理解するモデルで, structural model は, インタフェー スの階層構造を理解するモデルである [15]．

異なるユーザ属性が複数想定された場合は, それぞれの想 定ユーザを明確化するため，想定ユーザの項目を分ける.

\section{4. 操作タスクの可視化}

インタフェースを開発するためには, コンセプトの明確化 に加え,「シーケンス」と「階層構造」の関係について検討 する必要がある，各画面と画面に含まれる情報を構造化する
ことにより，各情報の関係が可視化される，各画面の情報に ついては，操作夕スクの分析により決定する。操作夕スクの 可視化の概要を図 5 に示す.

\begin{tabular}{|c|c|c|c|}
\hline \multicolumn{2}{|c|}{ 目標の明確化 } & \multicolumn{2}{|c|}{ 空調(温度，風量，予約)を行い,スムーズに操作してもらえること } \\
\hline \multirow{7}{*}{$\begin{array}{l}\text { シ } \\
\text { 즏 } \\
\text { 㕕 } \\
\text { の } \\
\text { 明 } \\
\text { 確 } \\
\text { 化 }\end{array}$} & \multirow{5}{*}{ システムの把握 } & 機能(專用·沉用) & 沨用機器 \\
\hline & & 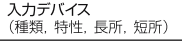 & 液晶バネル(3インチ) \\
\hline & & 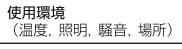 & 住宅.壁面, リビング \\
\hline & & 使用時間 & 5分 \\
\hline & & 運用システム & 個人が操作 \\
\hline & $\begin{array}{l}\text { インタフェース機能の明確化 } \\
\text { システムとユーザの能面での揢り当て }\end{array}$ & \multicolumn{2}{|c|}{ 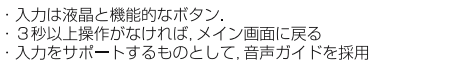 } \\
\hline & 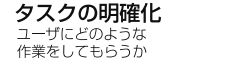 & \multicolumn{2}{|c|}{$\begin{array}{l}\text { ·液昆に表示されたた情報を読み取り、シートスイッチによる入力 } \\
\text { ・上下术タン゙選択, 決定 }\end{array}$} \\
\hline
\end{tabular}

\begin{tabular}{|c|c|c|c|c|}
\hline \multirow{10}{*}{$\begin{array}{l}\text { ユ } \\
\text { ! } \\
\text { ザ } \\
\text { の } \\
\text { 明 } \\
\text { 確 } \\
\text { 化 } \\
\text { メ } \\
\text { イ } \\
\text { ン } \\
\text { ᄀ } \\
\text { ザ }\end{array}$} & \multirow{4}{*}{ ユーザ層の明確化 } & 年 齢 & \multicolumn{2}{|c|}{$30 \sim 50$ 歳 } \\
\hline & & 性 別 & \multicolumn{2}{|c|}{ 男女問わない } \\
\hline & & 職 業 & \multicolumn{2}{|c|}{ 多様なユーザ } \\
\hline & & 年 収 & \multicolumn{2}{|c|}{ 500万円以上 } \\
\hline & \multirow{4}{*}{ ユーザレベルの明確化 } & 習熟度 & \multicolumn{2}{|c|}{ 問題なく習熟可能 } \\
\hline & & 教 育 & \multicolumn{2}{|c|}{ 大学以上 卒業 } \\
\hline & & 経 験 & \multicolumn{2}{|c|}{ ドットマトリクスタイフは経敛が少ない } \\
\hline & & \multicolumn{2}{|c|}{ 生活スタイル } & $\begin{array}{l}\text { ジプルな生活 } \\
\text { デザインン重視のインテリア } \\
\text { ロ八ス指 }\end{array}$ \\
\hline & \multirow{2}{*}{$\begin{array}{l}\text { ユーザのメンタルモデルの } \\
\text { 明確化 } \\
\text { ユーザ機器に対する擐作イメージ }\end{array}$} & \multicolumn{2}{|c|}{ Functional model } & 操作手順を理解できる \\
\hline & & \multicolumn{2}{|c|}{ Structural model } & 情報を構造的に理解できる \\
\hline \multirow{7}{*}{$\begin{array}{l}\text { ᄀ } \\
\text { ! } \\
\text { ザ } \\
\text { の } \\
\text { 明 } \\
\text { 確 } \\
\text { 化 } \\
\text { I }\end{array}$} & \multirow{4}{*}{ ユーザ層の明確化 } & 年 齢 & \multicolumn{2}{|c|}{60 歲 75歲 } \\
\hline & & 性 別 & \multicolumn{2}{|c|}{ 男女問わない } \\
\hline & & 職 業 & \multicolumn{2}{|c|}{ 大手企業, 団体職員 } \\
\hline & & 年 収 & \multicolumn{2}{|l|}{ 年金 } \\
\hline & \multirow{4}{*}{ ユーザレベルの明確化 } & 習熟度 & \multicolumn{2}{|c|}{ ある程度習熟可能 } \\
\hline & & 教 育 & \multicolumn{2}{|c|}{ 高等学校以上 卒業 } \\
\hline & & 経 験 & \multicolumn{2}{|c|}{ ドットマトリクスタイフの経铪がない } \\
\hline $\begin{array}{l}\text { ザ } \\
\text { ブ }\end{array}$ & & \multicolumn{2}{|c|}{ 生活スタイル } & 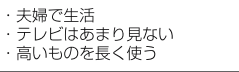 \\
\hline ザ & \multirow{2}{*}{$\begin{array}{l}\text { ユーザのメンタルモデルの } \\
\text { 明確化 } \\
\text { בーザ綝器に対する操作イメージ }\end{array}$} & \multicolumn{2}{|c|}{ Functional model } & 操作手順は何とか理解できる \\
\hline & & \multicolumn{2}{|c|}{ Structural model } & 情報の構造的な理解は難しい \\
\hline
\end{tabular}

図4 仕様表の記載例
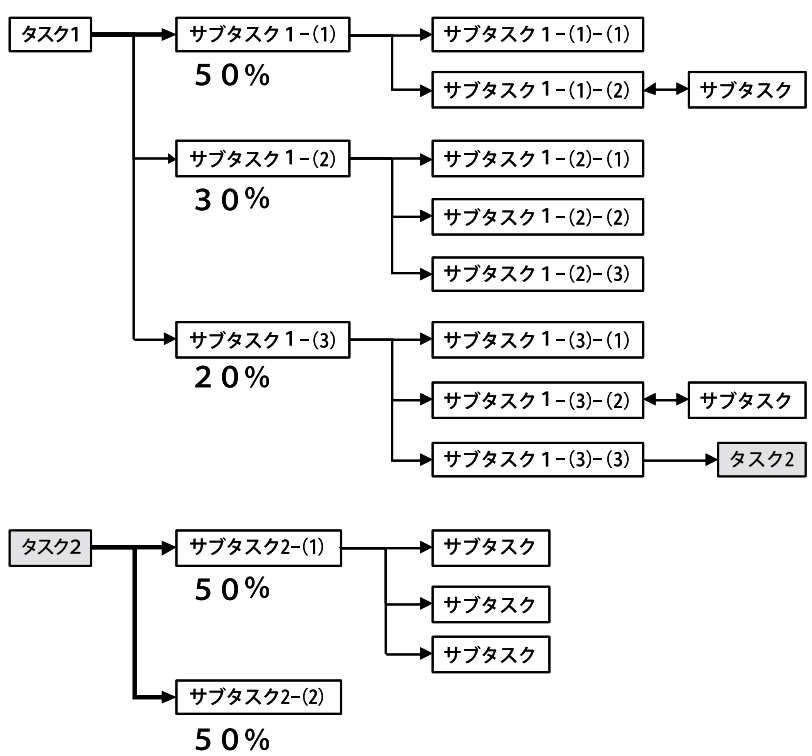

図5操作タスクの可視化 


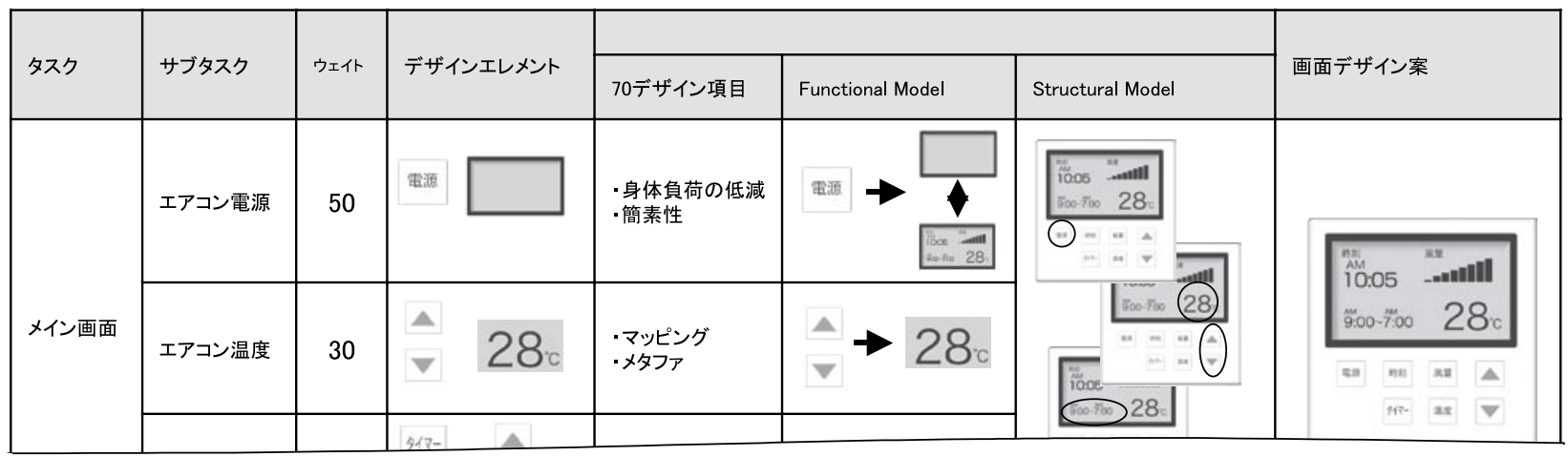

図6 インタフェースデザイン案の作成

操作タスクの可視化により構造化された各タスクにウェイ トを付ける。 このウエイト付けは, 構造化コンセプトから導 き出されるが, 操作タスクにウェイト付けを行うことで, ユー ザビリティ評価時に各タスクの重要性が確認できる.

タスクを結ぶラインの太さとウェイト值を対応させること で, タスク間の関係がより明確となる. タスク間の関係分析 と並行し, シーケンスの種類（逐次型, 並列型, ツリー型, 非循環ネットワーク型, 循環ネットワーク型, ハイパーリン ク型）［16］を決める．想定ユーザの特性（メンタルモデル など）を考え，階層構造や分岐（システムの分岐点に戻る， タスクの分岐点に戻る，一つ前のタスクに戻るなど）の種類 を検討する。

\section{5 インタフェースデザイン案の作成}

構造化コンセプトによる画面構成案と情報の構造化による 操作タスクフローをもとに，各画面のデザインを作成する.

図6に構築方法の概要を示す

各画面の「サブタスク」に対応した「ウェイト值」と「2.2 構造化コンセプト」で抽出した 70 デザイン項目との対応づ けを行う。デザインエレメントについても, 構造化コンセプ トと操作夕スクに基づくウェイト付けを行い, ウェイトに応 じたサイズ, 形状でデザインエレメントを作成する.例えば, ウエイトの高いデザインエレメントは，表示面積を大きく し，コントラストを強く強調するなど他との差異をつける。

デザインエレメントは, 2 種類のメンタルモデル (functional model, structural model) の観点からレイアウト検討を行う. functional modelでは,「手がかり」や「マッピング」を考 慮したレイアウトを行い, structural modelでは,「情報構造 の理解」や「容易な情報検索」を考慮したレイアウトを検討 する，最後に，各エレメントを統合し，画面デザイン案を作 成する。

\section{6 プロトタイプによる検証}

インタフェースデザインは, 各画面のレイアウトに加え, シーケンスの理解しやすさを検証することが重要である。そ のためには実際の操作の流れをシミュレーションし，ユーザ テストにより検証を行う必要がある [17]. 簡易なシミュレー ション方法として, ペーパープロトタイピング [18] が有
効とされている。しかし, 今後のインタフェースにおいて重 要な要素である「ボタンの点滅速度」や「操作を促すアニメー ション表現」 [19] について, ペーパープロトタイプではシ ミュレーションできない，そのため，アニメーションッール を使用したプロトタイプ作成が望ましい，また，実際の製品 に近い操作条件でシミュレーションするためには，マウス操 作よりもタッチパネルによる直接操作が適している。 そこ で, 本研究では, フラッシュ (Adobe 社製アニメーションッー ル）とタッチパネルモニタで構成したタッチパネルプロトタ イピング [20］を提案する。プロトタイプの作成手順を図7 に示す.「2.4 インタフェースデザイン案の作成」によるデ ザインエレメントごとに素材を作成する，各エレメントに は,「2.3 操作夕スク」に応じた数行のプログラムコードを 記載する. 動きを伴うエレメントは, 別途アニメーション画 像を用意しておく，それらを組み合わせたフラッシュアニ メーションを作成し, タッチパネルに表示させる. この手法 により，最終製品に近い操作シミュレーションが可能とな

(1)アニメーションソフトでプログラム

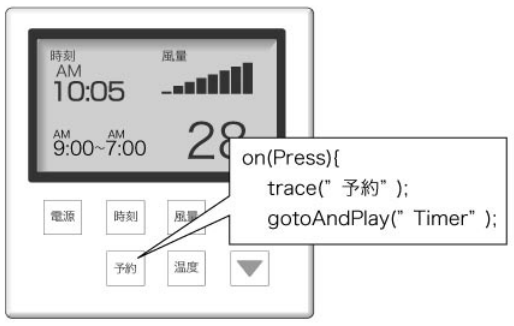

(2)タッチパネルでシミュレーション

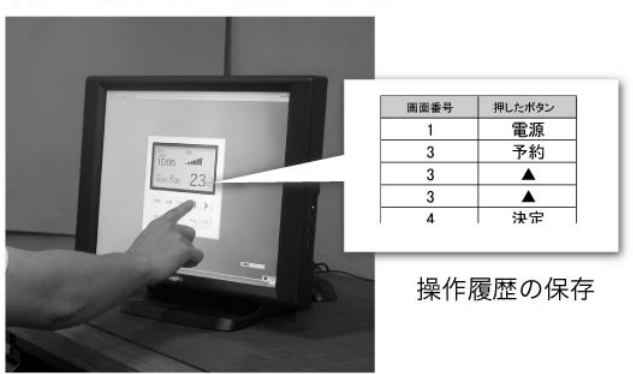

図7 タッチパネルプロトタイピング 
る. さらに, このプロトタイプは操作履歴の測定も容易とな るため, 達成時間等によるパフォーマンス測定を行う場合に おいても有効な手法である [21].

\section{7 購入後の使用実態調査}

商品購入後の使用実態調査を行い, 問題点を次期製品に フィードバックさせることが重要である. 開発プロセスにお いて，プロトコル分析によりデザイン案の評価を行ってい る. しかし, 時間経過で発生する問題点は, 上記評価だけで は発見できないため [22], 導入後に実態調査を行う必要が ある. 実態調査を行うことで発見された問題はユーザ要求事 項に変換し, 時期商品のコンセプト項目として活用できる.

以上のプロセスによりインタフェース構築を行うことで, これまでのHDTでは困難であった「具体的なインタフェー スへの落とし込み」が実現可能となる. 次項では, 実際の製 品開発に導入した事例の結果から, 本手法の有効性について 検証する.

\section{3. 提案手法の適応事例}

インタフェース開発手法の有効性を検証するため, 兵庫県 内の中小企業が開発したホームセキュリティシステムの操作 画面のインタフェース改善に, 本手法を適応した。

\section{1 ホームセキュリティシステムについて}

対象となったホームセキュリティシステムの外観を図 8 に 示す．外出前に操作画面を使ってセキュリティを設定しやす くするため，玄関先での使用を想定した設計がされていた. セキュリティロックがかかった状態で空やドアが開いた場 合, 部屋に設置されたウェブカメラにより部屋の映像が記録 され，家族の携帯電話にもメールで連絡が入るシステムと なっていた，さらに，このシステムは，各部屋に設置された 家電を制御するための遠隔家電制御機能やウェブ観覧機能が 付加されていた。

この製品のインタフェースは,「直感的に操作できるコン トローラ」という製品コンセプトに基づき, 社内会議で仕様 を決定し，2名のエンジニアが設計したものであった。

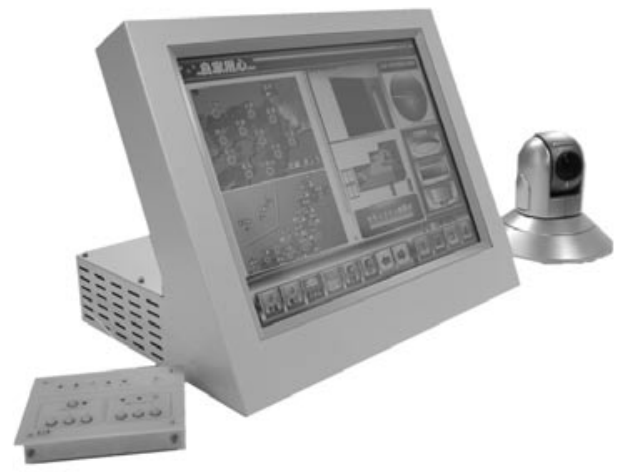

図8 ホームセキュリティシステムの概要

\section{2 改善プロセス}

\subsection{1 ユーザ要求事項の調査}

$3 \mathrm{P}$ タスク分析により現行製品の問題抽出を行い, 抽出さ れた問題の解決案をユーザ要求事項に変換した（図9). 夕 スク分析の結果，79項目の問題を抽出し，コストと製造面 から解決可能な 10 項目を選択した.

\subsection{2 構造化コンセプト作成}

3Pタスク分析により抽出したユーザ要求事項 10 項目をボ トムアップ式に階層化を行い,「一覧性の確保」「視認性の確 保」「安心できる操作感」「一貫性の確保」の4項目に分類（中 位項目）した（図 10）。下位項目と70デザイン項目を対応 させた構造化コンセプトを作成し，インタフェースデザイン の設計方針を決定した. 構造化コンセプトから, インタフェー スの設計方針として,「一覧性」簡素性」「マッピング」「フィー ドバック」「一貫性」を考慮し，設計することとなった．

\subsection{3 インタフェース仕様表の作成}

構造化コンセプトと並行し, インタフェースの仕様表を作 成した（図11）。対象製品は，戸建住宅への設置を想定して 設計されており, 新築購入時に住宅設備の一部として納品さ れる販売形体となっていたため, 新築購入者を想定ユーザと して設定した，想定ユーザは，メインユーザとサブユーザの 2 種類設定した。 メインユーザは，新築購入者である 28 40歳のユーザ像を設定した。サブユーザは, メインユーザ と同居人している両親を想定し, 仕様表を作成した.

\begin{tabular}{|c|c|c|c|c|c|}
\hline サブタスク & 情報入手面 & 理解·判断 & 操作 & 解決索 & ユーザ要求事項 \\
\hline 画面に触れる & & 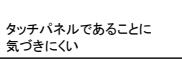 & & $\begin{array}{l}\text { スクリーンセー } \\
\text { 永一操作を } \\
\text { 工を促す }\end{array}$ & 操作を促すエ夫 \\
\hline 操作术タンを & & フィードバック音 & パネルの角度 & & $\begin{array}{l}\text { ·適切なつイードバッ } \\
\text { ?·押しやすすい角度 }\end{array}$ \\
\hline 画面が切り替 & $\begin{array}{l}\text { ボタンの数が少な } \\
\text { い. }\end{array}$ & 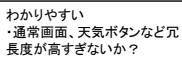 & & $\begin{array}{l}\text { 現在の状態が } \\
\text { わからなな }\end{array}$ & $\begin{array}{l}\text { ボ夕ンをかスタマイス } \\
\text { できな }\end{array}$ \\
\hline \multirow[t]{2}{*}{$\begin{array}{l}\text { インターネット } \\
\text { の } \\
\text { ホタンをを押す }\end{array}$} & & $\begin{array}{l}\text { ラ゙ハルが英語表記である(特 } \\
\text { にお年奇り) }\end{array}$ & 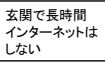 & $\begin{array}{l}\text { 周りの人には } \\
\text { うるさい }\end{array}$ & \\
\hline & & 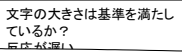 & 表示が掘い & & 項目をかスタマイス \\
\hline
\end{tabular}

図93Pタスク分析によるユーザ要求事項の抽出

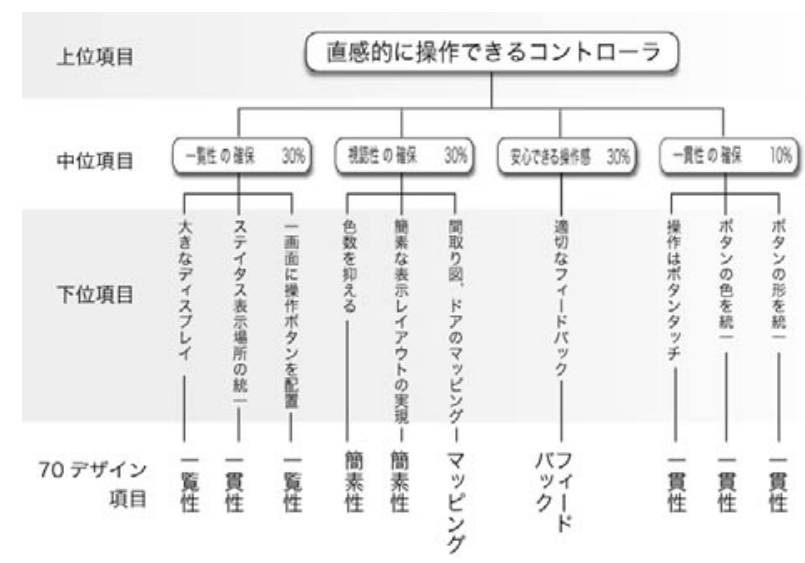

図10＼cjkstart構造化コンセプトによる方針決定 


\subsection{4 操作タスクの可視化}

構造化コンセプトとインタフェース仕様表に基づき, 操作 タスクの可視化を行った（図12）.

\begin{tabular}{|c|c|c|c|}
\hline \multicolumn{2}{|c|}{ 目標の明確化 } & \multicolumn{2}{|c|}{ セキュリティ操作をスムーズに操作してもらえること } \\
\hline \multirow{7}{*}{$\begin{array}{l}\text { シ } \\
\text { 즈 } \\
\text { テ } \\
\text { 允 } \\
\text { 把 } \\
\text { 握 }\end{array}$} & \multirow{5}{*}{ システムの把握 } & 機能 (専用·汎用) & 沉用機器 \\
\hline & & $\begin{array}{l}\text { 入カデバイス } \\
\text { (種類、特性, 長所, 短所) }\end{array}$ & 液晶式タッチバネル(17インチ) \\
\hline & & $\begin{array}{l}\text { 使用環境 } \\
\text { (温度, 照明, 䭷音, 場所) } \\
\end{array}$ & 住宅. 玄関 \\
\hline & & 使用時間 & 5分 \\
\hline & & 運用システムム & 個人が操作 \\
\hline & $\begin{array}{l}\text { インタフェース機能の明確化 } \\
\text { システムとユーザ機能面での制り当て }\end{array}$ & \multicolumn{2}{|c|}{ 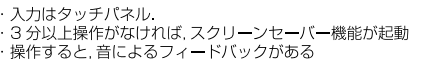 } \\
\hline & 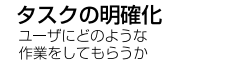 & \multicolumn{2}{|c|}{ ·画面に表示された情報を読み取り.タッチバネルによる入力 } \\
\hline
\end{tabular}

\begin{tabular}{|c|c|c|c|c|}
\hline \multirow{10}{*}{$\begin{array}{l}\text { ユ } \\
\text { I } \\
\text { ザ } \\
\text { の } \\
\text { 明 } \\
\text { 確 } \\
\text { 化 } \\
\text { メ } \\
\text { イ } \\
\text { ン } \\
\text { ユ } \\
\text { サ } \\
\text { ザ }\end{array}$} & \multirow{4}{*}{ ユーザ層の明確化 } & 年 齢 & \multicolumn{2}{|c|}{ 28 40歲 } \\
\hline & & 性 別 & \multicolumn{2}{|l|}{ 男女 } \\
\hline & & 職 業 & \multicolumn{2}{|c|}{ サラリーマン, 公務員 } \\
\hline & & 年 収 & \multicolumn{2}{|c|}{ 500万円以上 } \\
\hline & \multirow{4}{*}{ ユーザレベルの明確化 } & 習熟度 & \multicolumn{2}{|c|}{ 問題なく習羖可能 } \\
\hline & & 教 育 & \multicolumn{2}{|c|}{ 大学以上 卒業 } \\
\hline & & 経 験 & \multicolumn{2}{|c|}{ パソコンの使用絓竹あり } \\
\hline & & \multicolumn{2}{|c|}{ 生活スタイル } & 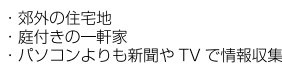 \\
\hline & \multirow{2}{*}{ 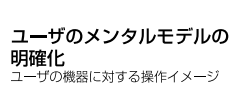 } & \multicolumn{2}{|c|}{ Functional model } & 操作手順を理解できる \\
\hline & & \multicolumn{2}{|c|}{ Structural model } & 情報を構造的に理解できる \\
\hline \multirow{7}{*}{$\begin{array}{l}\text { ᄀ } \\
\text { I } \\
\text { ザ } \\
\text { の } \\
\text { 明 } \\
\text { 確 } \\
\text { 化 }\end{array}$} & \multirow{4}{*}{ ユーザ層の明確化 } & 年 齢 & \multicolumn{2}{|c|}{ 60歲 75歲 } \\
\hline & & 性 別 & \multicolumn{2}{|l|}{ 男女 } \\
\hline & & 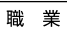 & \multicolumn{2}{|l|}{$\begin{array}{l}\text { 無職 } \\
\end{array}$} \\
\hline & & 年 収 & \multicolumn{2}{|l|}{ 年金 } \\
\hline & \multirow{4}{*}{ ユーザレベルの明確化 } & 習熟度 & \multicolumn{2}{|c|}{ ある程度習熟可能 } \\
\hline & & 教 育 & \multicolumn{2}{|c|}{ 高等学校以上 卒業 } \\
\hline & & 経 験 & \multicolumn{2}{|c|}{ パソコンの使用経験は少ない } \\
\hline $\begin{array}{l}\text { ザ } \\
\text { ユ }\end{array}$ & & \multicolumn{2}{|c|}{ 生活スタイル } & 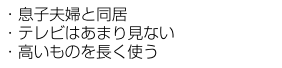 \\
\hline 1 & \multirow{2}{*}{$\begin{array}{l}\text { ユーザのメンタルモデルの } \\
\text { 明確化 }\end{array}$} & \multicolumn{2}{|c|}{ Functional model } & 操作手順は何とか理解できる \\
\hline 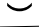 & & & & \\
\hline
\end{tabular}

図11 インタフェース仕様表の作成

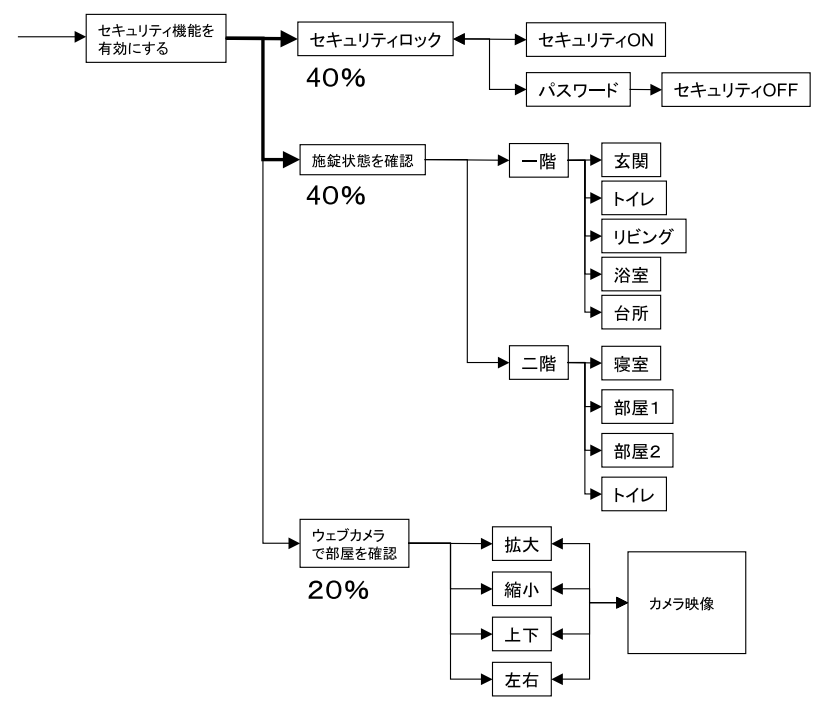

図12 操作タスクの可視化

\subsection{5 インタフェースデザイン案の作成}

構造化コンセプトとインタフェース仕様表, 可視化された 操作タスクに基づき，インタフェースデザイン案を作成した (図13).

\subsection{6 プロトタイプの作成}

タッチパネルプロトタイピングにより, 操作シミュレー ション可能なプロトタイプを作成した。

\section{4. 比較 実 験}

本研究で提案した手法の有効性を検証するため,「既存の 操作画面 (図 14上)」と「本手法により改善したインタフェー ス（図14下）」の比較実験を行った.

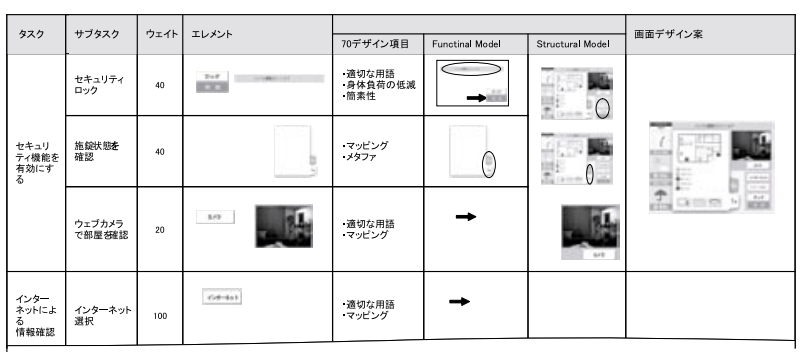

図13 インタフェース案の作成

現行 UI

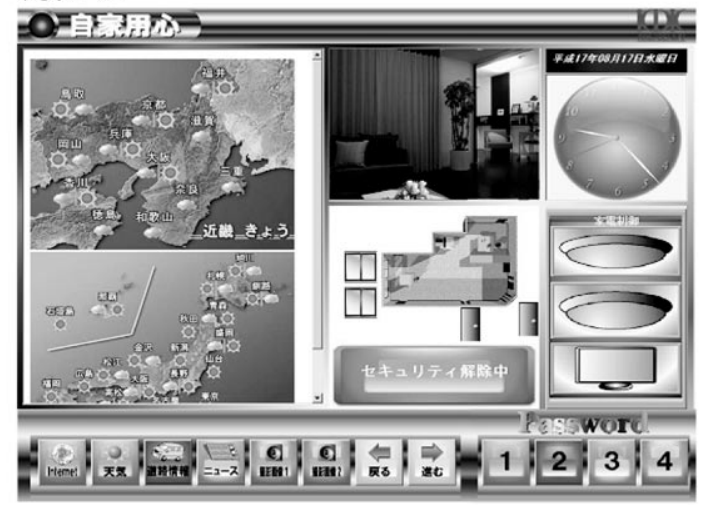

改善 UI

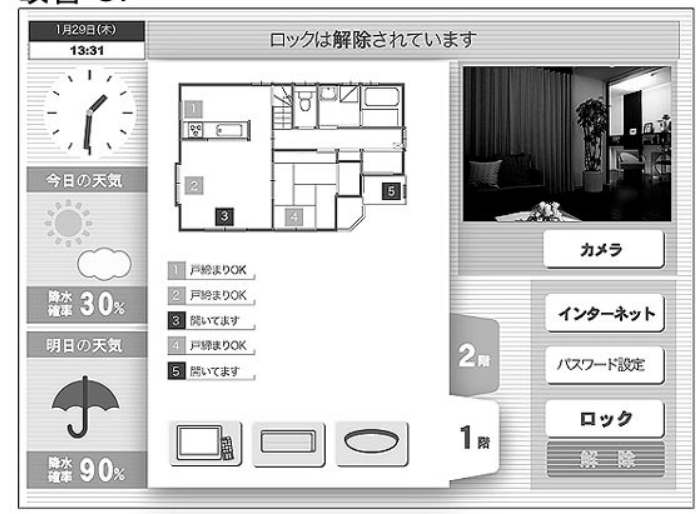

図14 インタフェースの比較 
プロトコル分析 $[23,24] に よ り$ 操作性の問題分析を行い, アンケートとインタビューによる主観評価 [25］から，コ ンセプトの妥当性について検証を行った.

\section{1 実 験 協力 者}

「既存の操作画面」と「本手法により開発したインタフェー ス」について，それぞれ別の協力者により実験を行った．

「既存の操作画面」での実験協力者は, 30 代男性5名, 女 性 2 名, 40 代男性 2 名, 女性 1 名の計 10 名（平均年齢 38.6 歳） であった、「開発したインタフェース」の実験協力者は, 30 代男性 3 名, 40 代男性 3 名の 6 名 (平均年齢 42 歳) であった。

\section{2 プロトコル分析による評価}

実験協力者には，ホームセキュリティシステムの概要と, 操作画面で制御可能な機能を説明後, 下記の 11 課題を実施 した。 なお，実験協力者に操作説明書は提示しなかった。

課題 1 ：鹿児島の天気を確認して下さい

課題 2：明日の天気を確認して下さい

課題 3：ドアや空が閉まっているか確認して下さい

課題 4：この製品には，留守中にドアや空が開くと警告音と 画面の点灯で侵入者を威嚇する機能が付いていま す.この機能を有効にして下さい.

課題 5：この製品には，留守中にドアや空が開くと警告音と 画面の担当で侵入者を威嚇する機能が付いていま す.この機能を解除して下さい. (パスワードは 1234 です)

課題 6：この製品には, 留守中にドアや空が開くと警告音と 画面の点灯で侵入者を威嚇する機能が付いていま す.この機能を有効にして下さい.

課題 7：室内灯をつけてください.

課題 8 ：パスワードの変更を行って下さい（現在のパスワー ドは1234です)

課題 9 ：現在，カメラはドアを向いています，右下に見えて いる植木を中央に見えるように移動してください，

課題 10 :インターネット機能を使用し, 今日の運勢を見て下 さい

課題 $11:$ 最初の画面に戻って下さい

課題 1, 2 は, 天気予報画面の操作性についての評価, 課 題3, 7, 11 は間取り図のマッピングについて, 課題4-6は セキュリテイ設定のためのボタンの位置について, 課題 8 は ボタンの配色および操作方法について, 課題 9 はウェブカメ ラの操作方法について評価した.

課題を実施中，できるだけ頭の中で考えていることを発話 してもらうことで, 戸惑いやわかりにくさに関する問題抽出 を行った，達成が難しいと判断した課題については，挙手に より課題未達成の意思表示をしてもらい, 次の課題へ移った。

\section{3 主 観 評 価}

アンケートとインタビューによる主観評価を行った。プロ トコル分析の課題が終了ごとに, 操作性についてアンケート
により操作性に関する評価を求めた。回答形式は「使いやす い」「やや使いやすい」「あまり使いやすくない」「使いにくい」 4段階評価とし,「使いやすい」を4点,「使いにくい」を 1 点として得点化した。最後にインタビューを行い，コンセプ 卜項目の妥当性の検証掞よび操作性に関する調查を行った. インタビューでは, アンケートの評価結果をもとに, その要 因について調査した。

\section{5. 実験結果および考察}

\section{1 プロトコル分析結果および考察}

各課題の操作達成率の内訳を図 15 に示す。上位が現行の インタフェース（以降，現行UI）で, 下位が本手法で構築 したインタフェース（以降, 改善UI）による達成度である。 操作達成度の定義は，「1，達成できなかった」「2．迷いなが ら達成」,「3：問題なく達成」の3段階とし, 観察によりそ の達成度を測定した。なお，操作ミスを繰り返し行ったが操 作を完了できたユーザは，「2. 迷いながら達成」としてカウ ントした，全体的に，改善UIの達成率が高かった。

課題 1（鹿児島の天気を確認して下さい）について, 現行 UIでは, メイン画面上に表示された日本地図をドラッグ操 作により移動させる必要があった。 それに対し, 改善UIで

\section{課題}

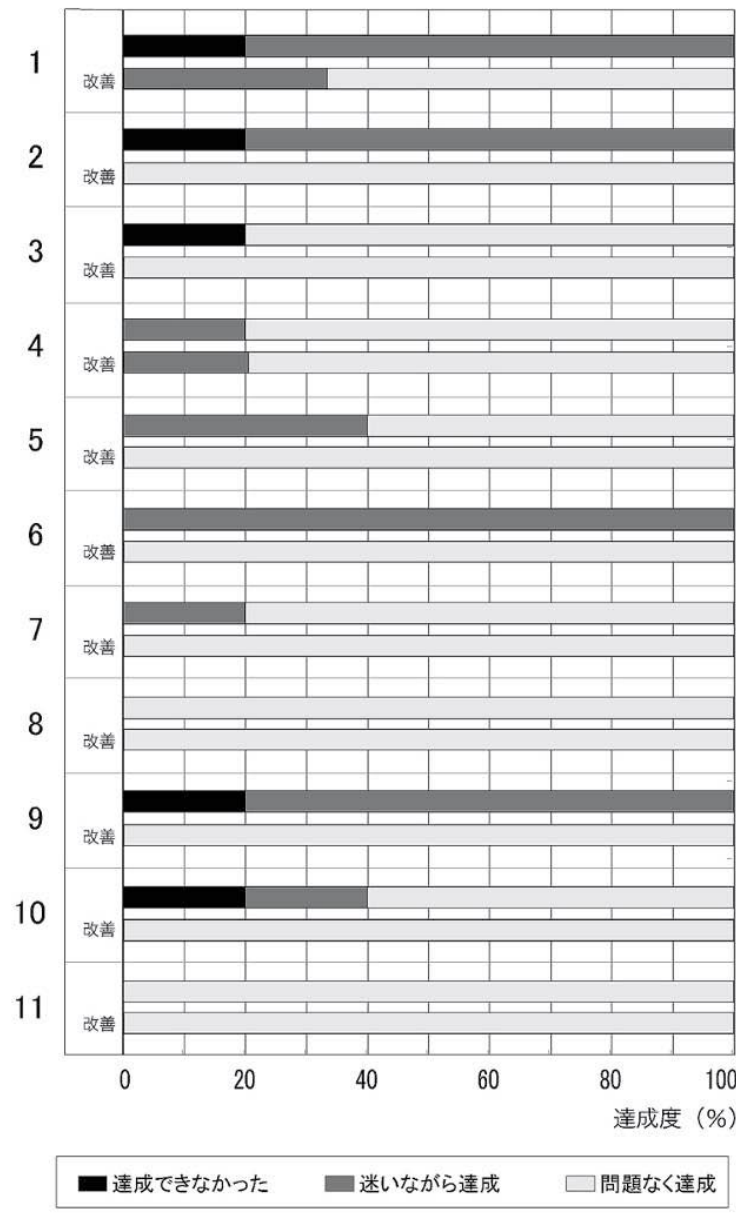

図 15 操作達成度の内訳 
は,「インターネット」ボタンを押し, ウィンドウをインタネッ トページに移動させ，天気の情報を確認する必要があった。 プロトコル分析の結果, 現行UIでは地図画面の移動方法に 戸惑うユーザが確認され（10人/ 10 人), 改善UIでは, 鹿 児島の天気の検索方法に戸惑うユーザが確認された（2人／ 6人). 改善UIのタスク達成率が良かった要因として, 構造 化コンセプト項目の 70 デザイン項目 (一貫性)に基づき,「ボ タン形状の統一」と「タッチ操作での操作に統一」したこと が考えられる．また, インタフェース仕様表から, メインユー ザは「情報を構造的に理解できる」と判断し，一画面の情報 量を減らし（デザイン項目：簡素性）, 階層構造による操作 タスクにした結果，一画面の情報が整理されていたことが影 響し，高い操作達成率が実現したと推測できる.

課題6（この製品には，留守中にドアや空が開くと警告音 と画面の点灯で侵入者を威嚇する機能が付いています。この 機能を有効にして下さい)は, 操作画面を使ってセキュリティ の機能を有効にする課題である. 現行UIでは, セキュリティ ボタンにステイタスが表示される仕様となっていた，改善 UIは, セキュリティボタンとは別の場所に, ステイタス表 示画面を付けていた。 これは，70デザイン項目（一貫性） および (一覧性) に基づきデザインしていた。ささらに，操作 タスクを可視化する際, ステイタスウインドウの項目のウェ イトを高くした $(60 \%)$ デザインとなっていた，そのため， 現在のセキュリティ状況が認知しやすいデザインとなってい ることで，ユーザの操作ミスが少なかったと考えられる．

課題 9 (現在, カメラはドアを向いています。右下に見え ている植木を中央に見えるように移動してください）は，部 屋に設置してあるウェブカメラの視点を遠隔操作する課題で ある. 現行UIでは, ウェブカメラの画像をタッチすると, タッ チした場所にカメラが移動する仕様となっていた．この操作 方法は, 特殊な操作方法であった点と, 操作の手がかりがな かったため, 操作できないユーザがいた（2人/10人）. 改 善UIでは, 天気確認と同様, 別画面で操作する仕様となっ ており，全員が操作できた．コンセプト項目（一貫性）に基 づいた設計がされており, 課題 1 の時と同類の方法で操作可 能であったことが, ユーザに理解しやすい操作方法となって いたと考えられる.

課題 10 と 11 では, 改善UIのコンセプト項目「操作はボ タンタッチのみ」「適切なフィードバック実現」を反映した インタフェースとなっているのに対し，現行UIではドラッ グ操作とタッチ操作が混在していたため, 操作達成度に差が 出たと推測される.

現行UIは，画面の現在状況や設定状態が確認できないイ ンタフェースであったため, 課題実施中, 操作を戸惑ってい る状況が確認された。 また, 機器のフィードバックが明確で なかったことから, 同じボタンを複数回押し, 操作を繰り返 す傾向が見られた (4人/10人). それに対し, 改善UIでは, 機器の状態を常に表示するエリアを設定しており（70デザ イン項目：一貫性), 操作を行った際に必ず音が鳴るように していた（70デザイン項目：フィードバック）ため, 操作
を戸惑うユーザも少なく全般的に操作達成率も良かった。

\section{2 主観評価の結果および考察}

使いやすさの主観評価として, 各課題の実験後に取得した

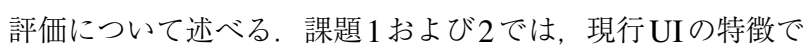
あった「大きな天気表示」が，ユーザにとってあまり重要な 項目でないことがわかった ( 8 人 $/ 10$ 人). また，各部屋の 施錠状態やウェブカメラの映像画面などセキュリティに関す る情報について，もう少しわかりやすく表示して欲しいとの 意見があった $(5$ 人 $/ 10$ 人). それに対し改善UIでは, セキュ リティ関係の情報が大きく表示されたデザインとなってお り, ユーザの要求に応えたデザインであった。この背景には, 本手法「タスクの可視化」に扔いて, 設定タスク「セキュリ ティをかける」タスクのサブタスク「部屋の施錠状態を確認」 に全体の 40 パーセントのウェイトが置かれており，部屋の 施錠状態を確認するための表示面積を大きくしていたことが 挙げられる，表示部と操作部のレイアウトについても，部屋 の間取り図に出入り口の施錠状態がマッピング（70デザイ ン項目）されたデザインとなっていたことから，課題 3 に対 してユーザ全員が使いやすいと感じたと推測される.

現行UIのカラフルなパスワード設定ボタンに対し, 好ま しく思っていないユーザが多く，使いにくいと感じているこ とが確認された（6人／10人). 改善UIでは，70デザイン 項目 (簡素性) に基づき, 一画面に使用する色数も制限した ことが使いやすいと感じられた要因として考えられる。

現状UIでは，ほとんどの機能を一画面に表示させたデザ インになっていたのに対し, 改善UIでは一部の機能を階層 構造にすることで,一画面の情報量を減らしていた。これは, 「インタフェース仕様表」に扔いて, 想定ユーザ（メインユー ザ）が「パソコン経験あり」で「情報構造の把握ができる」 メンタルモデルを持っているユーザと判断し, 階層構造のイ ンタフェースにしていた，また，想定ユーザ（サブユーザ） が 65 歳以上であることから, 深い階層構造のインタフェー スは避け，1タスクで最高3階層までに制限した[27].

さらに,「使いやすい」「やや使いやすい」「やや使いにくい」 「使いにくい」の4段階で評価をしてもらい,「使いやすい」を 4点,「使いにくい」を1点として得点化した結果（表1）からも， 本手法により改善したインタフェースの有効性が確認できる.

表1 各タスクの尺度評価の平均点と標準偏差

\begin{tabular}{|c|c|c|c|c|}
\hline \multirow{2}{*}{ 課題 } & \multicolumn{2}{|c|}{ 現行UI } & \multicolumn{2}{c|}{ 改善UI } \\
\cline { 2 - 5 } & 平均 & SD & 平均 & SD \\
\hline 1 & 2.30 & 0.48 & 3.67 & 0.52 \\
\hline 2 & 2.00 & 1.05 & 4.00 & 0.00 \\
\hline 3 & 2.20 & 1.03 & 3.33 & 0.52 \\
\hline 4 & 2.20 & 1.14 & 2.67 & 1.37 \\
\hline 5 & 3.20 & 0.79 & 3.67 & 0.52 \\
\hline 6 & 2.00 & 1.33 & 4.00 & 0.00 \\
\hline 7 & 2.90 & 0.88 & 3.67 & 0.52 \\
\hline 8 & 3.60 & 0.70 & 4.00 & 0.00 \\
\hline 9 & 1.80 & 0.92 & 3.67 & 0.52 \\
\hline 10 & 2.80 & 1.55 & 4.00 & 0.00 \\
\hline 11 & 3.70 & 0.48 & 4.00 & 0.00 \\
\hline
\end{tabular}


ユーザが改善UIを操作しやすいと感じた要因として, 本 手法により，一貫したインタフェースを構築できたことが考 えられる. また, 本手法によりコンセプトとインタフェース の仕様, 操作夕スクが明確となり，インタフェースに対する 分析が行いやすくなったことも確認できた.

\section{6. まとめと今後の課題}

本研究は, 中小企業の現場で活用可能なインタフェース開 発を目的に，これまで中小企業の現場で活用されていた HDT手法をインタフェースデザイン手法として再構築し た. 以下に結論を示す、

・HDTの「デザイン案の作成」プロセスでは詳細に決まっ ていなかった「インタフェースのシーケンス」および「情 報構造」の可視化を行い, インタフェースを構築する手法 を提案した.

・既存のホームセキュリティシステムのインタフェースを対 象に, 本手法によるインタフェース改善を行い, 現行のイ ンタフェースとユーザテストにより比較した結果, 本手法 の有効性が認められた

・本手法により, インタフェースを構築することで, 設計方 針や操作夕スクが明確となるため, 開発後の分析や改善策 を検討する際にも有効な手法である.

・本手法は, 中小企業の現場で活用されているHDTに基づ き開発された手法であるため, 中小企業で導入しやすく, 今後の活用が期待できる.

今後は,インタフェース仕様表の項目を精緻化し, 想定ユー ザとインタフェースデザインの関連について研究を進める予 定である。また，これらの改良と並行して，実際のインタ フェース開発に本手法を活用し，検証事例と分析により，手 法の高度化を進めたい.

\section{謝 辞}

今回の研究に協力して頂いた和歌山大学の岡田衛様, 熊田 俊昭様, 吉川嘉修様, 下野文弘様に深く感謝致します.

また，今回の研究の評価対象製品であるホームセキュリ ティシステムは, 株式会社晃栄電子様に製品を提供していた だきました。この場を借りてお礼を申し上げます。

\section{参考文 献}

［1］山岡俊樹 編著：デザインセクションに見るデザインマネ ジメントの要諦，海文堂出版，pp.121-137，2005.

[2］山岡俊樹：ヒューマンデザインテクノロジー入門, 森北出 版, 2003 .

［3］澤島秀成，山本政男，木田裕之，杉山陽二，畠中順子： HDT（Human Design technology）による人間中心設計に ついて, 奈良県工業技術センター研究報告 No.29, pp.34-38, 2003.
４4］西村睦夫, 浜芳典, 田村正雄, 坪山尚子, 趙小明, 染谷透, 山岡俊樹, 高見到, 堀田英志 ; ヒューマンデザインテクノ ロジーに基づく活用事例案（2），デザイン学研究. 研究発 表大会概要集 (47), pp.350-351, 2001.

[5] 平田一郎, 後藤泰徳, 磯野禎三, 有年雅俊 : 次世代インタ ラクションデザイン研究会, 兵庫県立工業技術センター研 究報告, 2008 .

[6] 山岡俊樹：ヒューマンデザインテクノロジー入門, 森北出 版, pp.23-25, 2003.

［7］山岡俊樹 編著：ハード・ソフトデザインの人間工学講義, 武蔵野美術大学出版局, pp.150-161, 2002.

[8］山岡俊樹：ヒトにやさしいモノづくり〜「ヒューマンデザ インテクノロジー」第 2 回ユーザニーズを探る $<1>$, ダ イワアーク，8月号，pp.34-35, 2001.

[9] 高橋信：Excelで学ぶコレスポンデンス分析, オーム社, 2005 .

[10] 井上勝雄 : パソコンで学ぶ多変量解析の考え方, 丸善, pp.123-139, 1998.

[11]神田範明編著：商品企画七つの道具, 日科技連, pp.111-133, 1995.

[12］山岡俊樹：ヒューマンデザインテクノロジー入門，森北出 版, pp.101-142, 2003.

[13] Jenny Preece, Yvonne Rogers, Helen Sharp: Human-ComputerInteraction, pp.123-139, Addison-Wesley Publishing, 1994.

[14] 林昌俊, 森亮太, 吉岡英俊, 山岡俊樹 : 電卓使用時の高齢 者のメンタルモデル構築過程の把握，平成 18 年度日本人 間工学会関西支部大会講演論文集, pp.13-16, 2006.

[15] 平田一郎, 山岡俊樹 : 高齢者の電子機器の操作に関する一 考察, 平成 20 年度日本人間工学会関西支部大会講演論文 集, pp.137-140, 2008.

[16] 社団法人人間生活工学研究センター編：ワークショップ人 間生活工学 第3巻, 丸善, pp.99-101, 2005.

[17］山崎和彦, 吉武良治, 松田美奈子：使いやすさのためのデ ザインーユーザセンタードデザイン, pp.135-151, 丸善, 2004.

[18］樽本徹也：ユーザビリティエンジニアリングーユーザ調査 とユーザビリティ評価実践テクニック，オーム社, pp.72-80, 2005.

[19］小林祐毅, 加藤善裕, 西田善彦, 水野喜信, 吉田光一, 吉 田真由子, 山岡俊樹：製品とユーザのやり取り（インタラ クション）に着目した製品評価手法の考察, 平成 18 年度 日本人間工学会関西支部大会講演論文集, pp.5-8, 2006.

[20] 平田一郎, 後藤泰徳, 中本裕之, 後藤浩二, 富田友樹: ユ一 ザビリティ評価によるデザイン改善手法の開発, 兵庫県立 工業技術センター研究報告代 16 号, pp.44-45, 2007.

[21］吉田昇平，山岡俊樹：高齢者を対象としたGUI の構造パ ターンに関するユーザビリティの研究, 第 5 回日本感性工 学会春季大会・KEER2009予稿集, 11C-04, 2009.

[22] 新家敦 ; ユビキタスセンサを利用した行動観察手法の開発 
- In-Situ Ergonomics - , 日本人間工学会誌第 42 巻特別 号, pp.30-31, 2006.

[23] 海保博之, 原田悦子編：プロトコル分析入門, 新曜社, 1993.

[24] 黒須正明, 伊藤昌子, 時津倫子：ユーザ工学入門, 共立出 版, p.131， 1999.

[25] 福田忠彦研究室編：人間工学ガイド 感性を科学する方 法, サイエンティスト社, pp.4-5, 2004.

[26］川喜田二郎：発想法, 中公文庫, p.99, 1967.

[27] 平田一郎, 吉田昇平, 山岡俊樹 : 高齢者の電子機器操作に関 する一考察, 日本人間工学会第 45 巻特別号, pp.424-425, 2009.

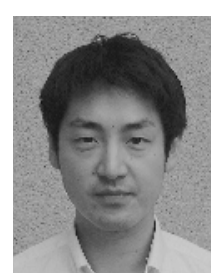

\section{平田 一郎 (正会員)}

1998 年神戸芸術工科大学芸術工学部工業デ ザイン学科プロダクトデザインコース卒業, 同年兵庫県立工業技術センター産業デザイン センター入所, 2002 年より兵庫県立工業技 術センターものづくり開発部研究員. 2007 年和歌山大学大学院システム工学研究科博士後期課程入学, 現 在にいたる. 専門：ユーザインタフェースデザイン，プロダク トデザイン, 人間工学.

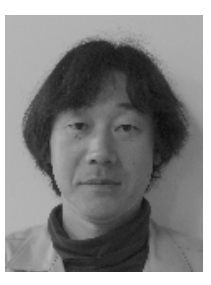

後藤 泰徳（非会員）

1987 年武蔵野美術大学造形学部基礎デザイ ン学科卒業, 1989 年 1990 年国際協力事業 団（委嘱）ネパール工業省/家内工業局, 1992 年 兵庫県立工業技術センター産業デザ インセンター入所, 2002 年より兵庫県立工 業技術センターものづくり開発部主任研究員. 2006 2008 年 神戸芸術工科大学非常勤講師. 専門: プロダクトデザイン, ロボッ トデザイン, 人間工学.

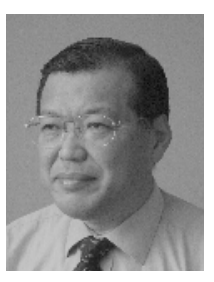

\section{山岡 俊樹 (正会員)}

1971 年千葉大学工学部工業意匠学科, 同年 東京芝浦電気(株) 入社, 1991 年千葉大学自 然科学研究科博士課程修了, 1998 年和歌山 大学システム工学部デザイン情報学科教授 (学術博士), 現在にいたる。専門：人間工学 (日本人間工学会認定人間工学専門家)，ユーザインタフェー ス, 工業デザイン, 製品開発, サービス工学, 観察工学, ユニバー サルデザイン, デザインマネージメント, 米国人間工学会 (HFES), ISO - TC159 (人間工学) 委員, Universal Access in the Information Society（UAIS）Journalの editor, 他を担当. 